\title{
動脈硬化の第一段階としての血管内皮障害
}

\author{
東幸仁
}

要旨

動脈硬化発症における多彩な分子機能が明らかにされている. 酸化ストレス, 炎症, 脂質の蓄積など が単独にあるいは相互作用しながら動脈硬化に関与している.これらの因子による直接あるいは血管壁 細胞を介した血管内皮への障害機転により結果的に血管内皮障害を惹起する. 血管内皮障害は, 動脈硬 化発症の引き金となり, 動脈硬化の進展から粥種の破綻による心筋梗塞, 脳卒中などの血管合併症をき たす.血管内皮は動脈硬化の進展とともに障害され，障害された血管内皮がさらに動脈硬化を進展させ るという悪循環を形成しながら動脈硬化形成に深く関与すると考えられている.動脈硬化の第一段階と して血管内皮障害発症メカニズムの解明や治療の介入による血管内皮障害改善に伴う血管合併症発症抑 制への期待は大きい. 動脈硬化は血管代謝（血管内皮機能）という側面からも捉えることができる.

[日内会誌 $96: 1717 \sim 1723 ， 2007$ ]

Key words : 血管内皮機能, 一酸化窒素, 動脈硬化, サロゲートエンドポイント

はじめに

1980 年に米国の生理学者であるFurchgottら ${ }^{1)}$ によりエポックメーキングな発見（内皮依存性 血管弛緩因子：EDRF)がなされて, 血管内皮に 関する研究がスタートして 30 年近くが経過した. これまでの膨大な知見の集積に加えて, 現在も， 血管内皮に関する基礎的臨床的な新たな発見や 可能性が報告されている. 動脈硬化においては, 血管内皮機能が血管機能自体を制御し, 動脈硬 化の発症・維持・進展・破綻に重要な役割をは たしていることが明らかとなった，特に，動脈 硬化の第一段階として血管内皮障害の重要性が 注目されている。従って，血管内皮機能を制御 することは, 心血管病発症を制御できるといっ ても過言ではないかもしれない, 本稿では, 動

ひがしゆきひと:広島大学大学院医歯薬学総合研究 科心臟血管生理医学
脈硬化の第一段階としての血管内皮機能障害の 臨床的意義, 血管内皮機能障害のメカニズム, 血管内皮機能の予後規定因子としてあるいは治 療ターゲットとしての可能性について概説した w.

\section{1. 血管内皮の解剖・生理}

血管内皮は解剖学的には血管の最も内層に位 置しており，一層の細胞層よりなっている．血 管内皮は血管内腔と血管壁を隔てるバリアーの ようなものと考えられていた，全身の血管内皮 を集めることができると仮定すると, 総重量は 肝臓に匹敵し，一面に敷き詰めることができれ ば，総面積はテニスコート 6 面分に，一列に繋 げることができるとすれば 10 万キロメートル， 地球 2 周半にも相当する (図 1). 1980 年, FurchgottらによりEDRFが発見され， 7 年後には PalmerやIgnarroらによりEDRFの本体が一酸化 


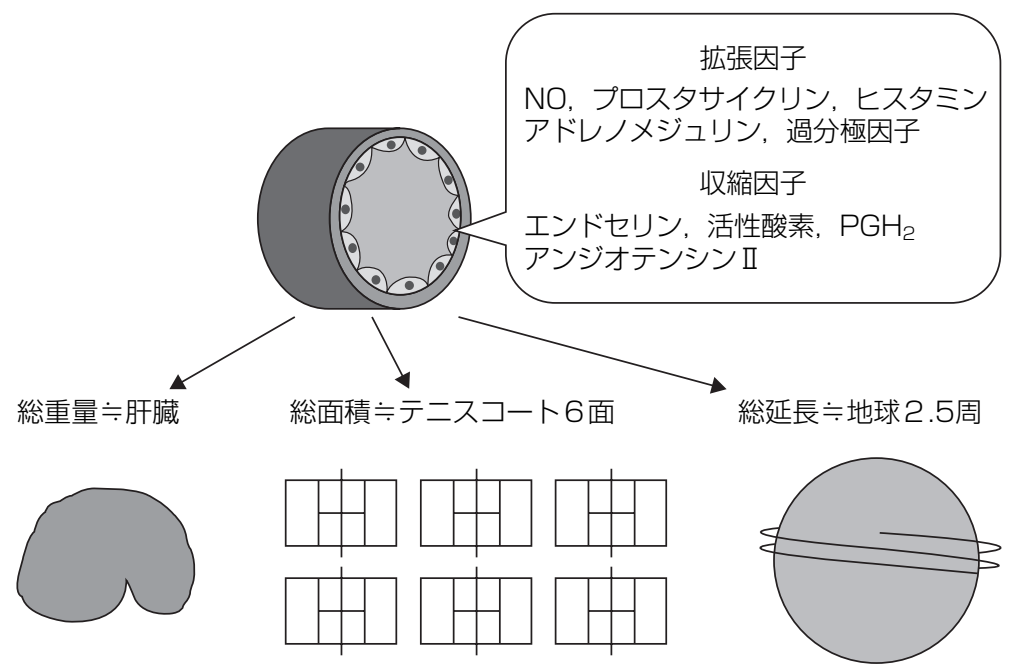

図 1. 血管内皮の構造および生理的意義

窒素（NO）であることが証明された。その間， その後も血管内皮より血管拡張因子としてNO 以外にもプロスタグランジン $\mathrm{I}_{2}, \mathrm{C}$ 型ナトリウム 利尿ペプチド，内皮由来血管過分極因子，さら に血管収縮因子としてエンドセリン，アンジオ テンシンII (Ang II), プロスタグランジン $\mathrm{H}_{2}$,

トロンボキサン $\mathrm{A}_{2}$ といった様々な生理活性物質 が産生・分泌されることが明らかとなってきた2). これら生理活性物質の中でも特に, NOは動脈硬 化において非常に重要な役割をはたしている. 正常な血管内皮は血管の拡張と収縮, 血管平滑 の増殖と抗増殖, 凝固と抗凝固作用, 炎症と抗 炎症作用，酸化と抗酸化作用を有しておりこれ らのバランスにより血管トーヌスや血管構造の 調節・維持に働いている。血管内皮自体の重量 や表面積ばかりでなく多様な生理活性物質の産 生制御能を有することより，血管内皮は全身に 存在するヒト最大の内分泌器官とも称せられる.

\section{2. 血管内皮機能と動脈硬化}

血管内皮が障害されると正常な血管内皮が本 来有している動脈硬化と抗動脈硬化のバランス が崩れ血管トーヌスや血管構造の破綻へとつな
がる，血管内皮を障害する病態，因子はよく知 られている。高血圧, 高脂血症, 糖尿病などの 病態, 肥満, 運動不足, 喫煙, 塩分の過剩摂取, 閉経などの因子が血管内皮の障害に働く ${ }^{3,4)}$. 動 脈硬化は血管内皮機能傷害を第一段階として発 症し, 進展する。ささらに進行すれば心血管合併 症を惹起すると考えられている（図 2). 多くの 研究により，血管内皮機能の評価が予後の規定 因子となりうることが報告されている ${ }^{5,6)}$. 高血 圧患者を血管内皮依存性弛緩物質アセチルコリ ンに対する前腕血流量の反応性により 3 群に分 けて, 予後を 7 年間に渡り追跡した前向き研究 では，アセチルコリン低反応群（血管内皮機能 傷害高度群) はアセチルコリン高反応群に比し, イベント発生率が 3 倍以上であったと報告して いる $(\text { 図 3 })^{5)}$. 閉経後高血圧女性において, 6 カ月間の降圧治療で降圧の程度は同等ながらflowmediated dilation (FMD) の改善群と不変群の 2 群で 5 年後の心血管イベント発症率を検討した ところ, FMD不変群でのイベント発症が有為に 増加していた。 また，冠動脈疾患患者において も，アセチルコリン投与による前腕血流量ある いは冠動脈血管径の反応性や前腕のFMDの検討 により，血管内皮機能が予後を規定する因子で 

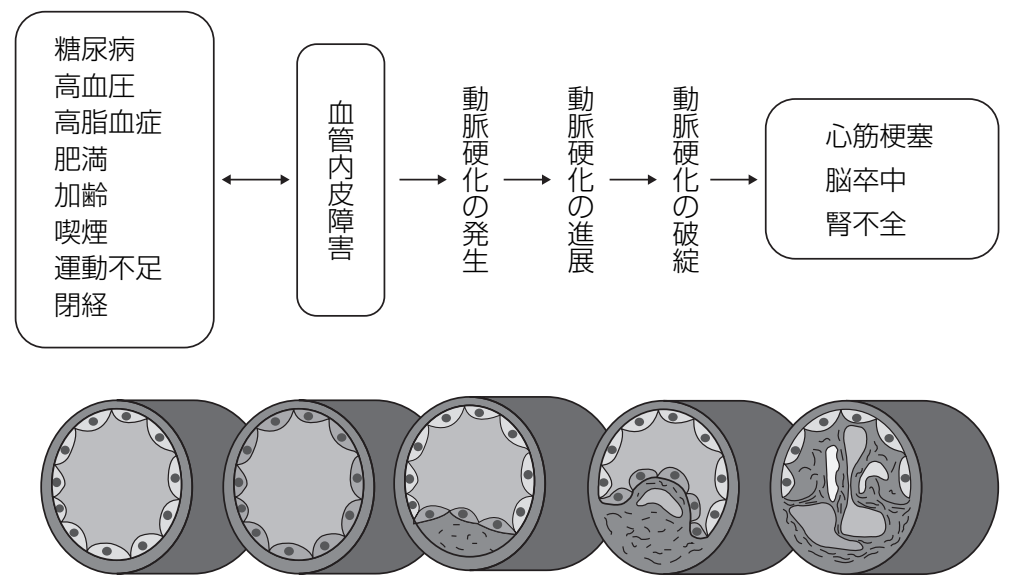

図 2. 血管内皮機能異常を第一段階とした動脈硬化発症から心血管合併症へのプロセス

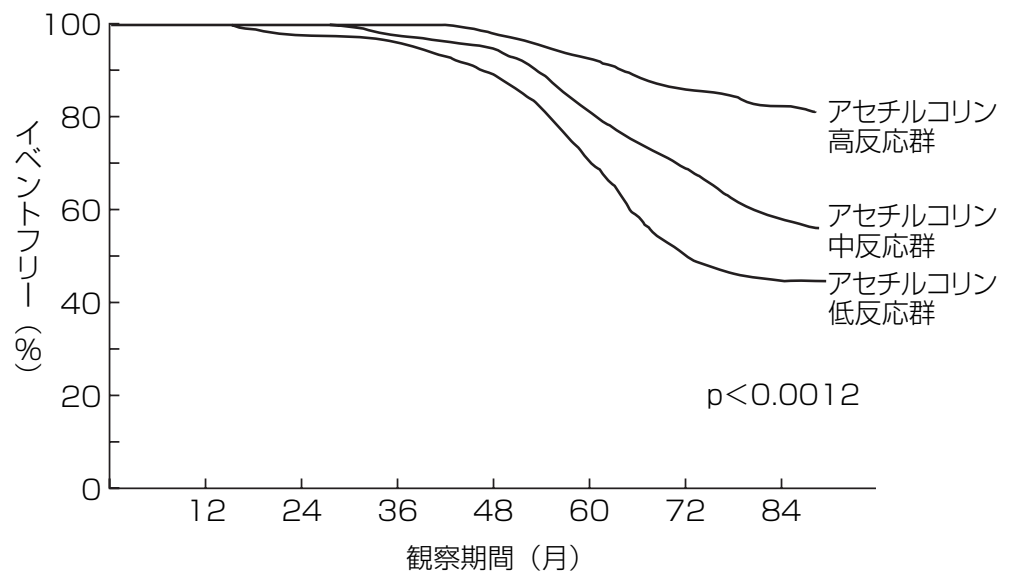

図 3. アセチルコリンに対する反応性により分類されたろ群での心血管イベント非発症率(文献 5 より改変引用)

あることが確認されている ${ }^{6)}$. 血管の手術を受け た患者のFMDを評価したところ,FMDの低下例 は周術期合併症を起こしやすいという報告もあ る．血管内皮機能は心血管病発症の第一段階と して働くだけではなく規定因子としても認知さ れるようになった，興味深いことに，Werner らは77, 冠動脈疾患を有する患者において, 登録 時に血中血管内皮前駆細胞数で 3 群に分けて 12 月フォローアップしたところ，血中血管内皮前 駆細胞数の少ない群では心筋梗塞, 再狭窄, 入 院，心血管死などの心血管イベントが明らかに 増加していたと報告している（図 4)。これらの
結果は血中の血管内皮前駆細胞数が心血管イベ ント発症の規定因子となり得ることを示唆して いる.

\section{3. 血管内皮機能異常のメカニズム}

血管内皮機能異常を惹起する様々なメカニズ ムが想定されている (図 5). 最も重要なのはNO の生物学的活性の低下 $(\mathrm{NO}$ 自体の産生低下もし くはNOの不活性化あるいは両者が同時に存在す る)によるものである．NO産生低下の機序とし ては,アゴニストに対する受容体の異常, 受容 


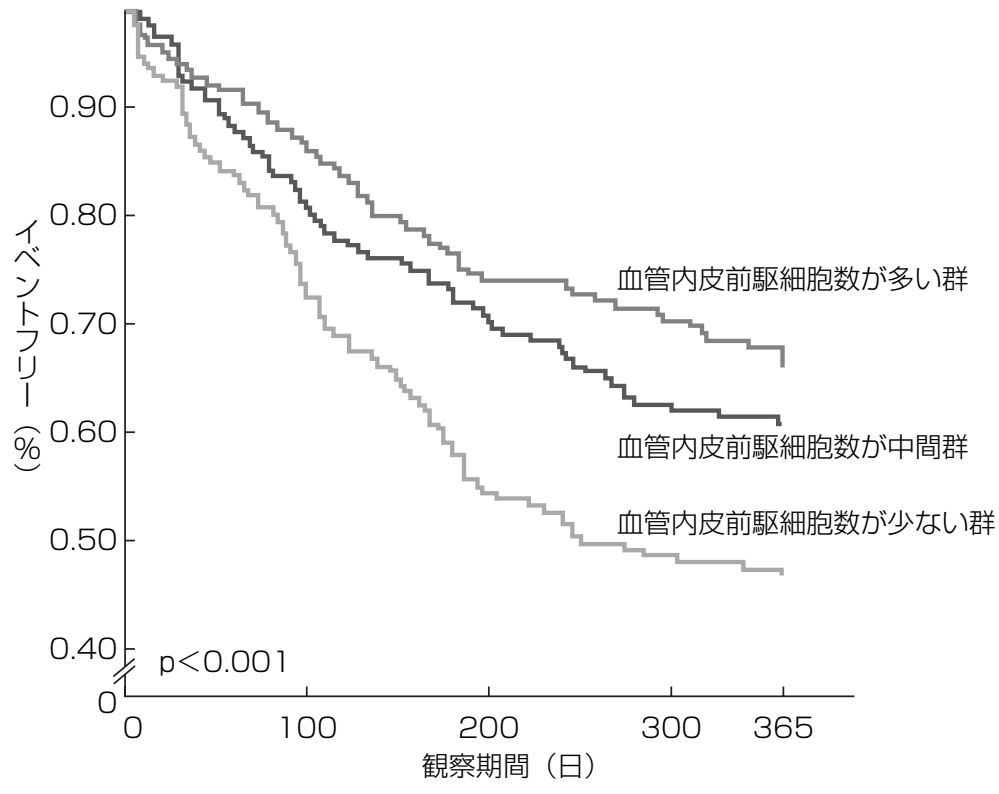

図 4. 血中血管内皮前駆細胞数と予後（文献 7 より改変引用）

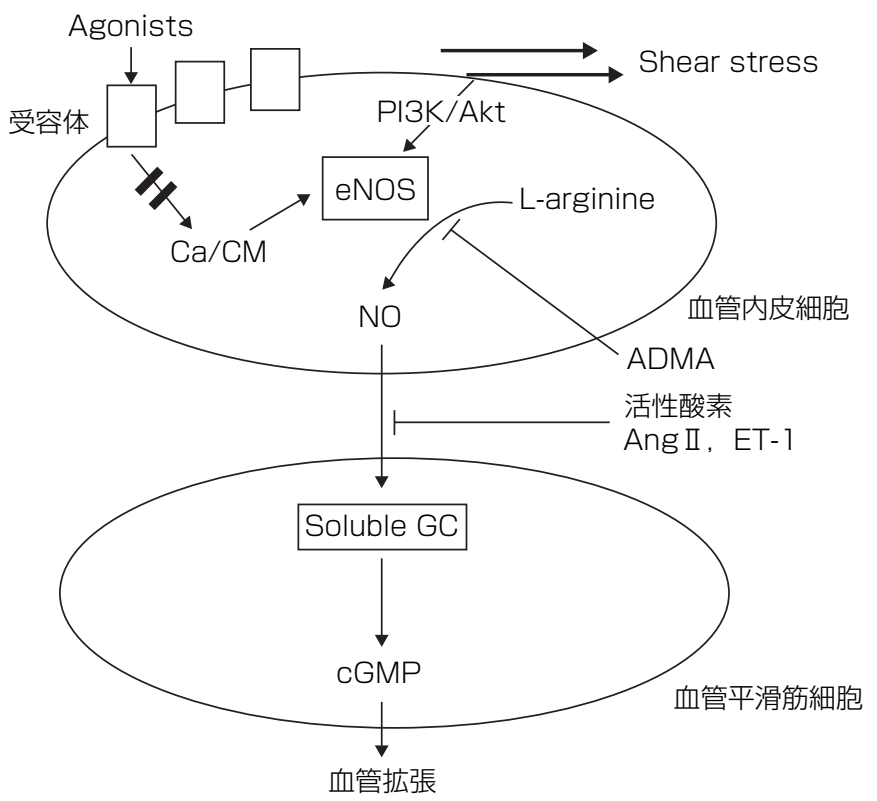

想定される機序

受容体の異常

シェアストレスの減弱・異常

情報伝達系の異常

eNOS活性の低下

L-arginine利用能の低下 細胞內L-arginineの不足

ADMAの増加

血管収縮因子の増加

NOの不活性化

NOの拡散障害

soluble GC活性の低下

PKG活性の低下

図 5. 血管拡張のプロセスと血管内皮機能異常の機序

体結合後の情報伝達系の異常, シェアストレス の減弱や異常，内皮型NO合成酵素（eNOS）の 異常, NOの基質としてのL-arginineの不足が考 えられる. 動脈硬化性疾患や動脈硬化実験動物
モデルにおいて血管内皮非依存性血管弛緩物質 に対する反応性は障害されていないことより， 血管平滑筋でのsoluble GCの活性低下やPKG活性 の低下の関与は否定的である. また, NO産生低 
下以外の機序としては酸化ラジカルの産生増加 に伴うNO捕捉の増加（NOの不活性化）が重要 である。

高血圧, 糖尿病, 高脂血症あるいは喫煙, 加 歯、肥満といった危険因子では，いずれも活性 酸素が過剩な状態（酸化ストレス）にあること が確認されている. 最近, 活性酸素の産生増加 によるNO捕捉（NOの不活性化）が血管内皮機 能異常の機序の一つとして注目されている. 活 性酸素はNOと非常に高い結合親和性を有してお り, NOの不活性化に寄与する.ささらに, 産生さ れた活性酸素はNOと結合することにより非常に 強い細胞毒性を有するペルオキシナイトライト に変換される，これにより，血管壁細胞の直接 の障害, さらに血管内皮細胞や血管平滑筋細胞 でのNOの生物学的活性の低下を生じる. 酸化ス トレス状態はNOの産生低下とNOの不活性化に より血管内皮機能障害に働き, 血管内皮機能障 害はフィードバックして動脈硬化を進展させる 悪循環を形成する。また，酸化ストレス状態は 血管内皮機能障害惹起するとともに, レドック ス感受性の血管平滑筋増殖, 肥大, アポトーシ スを誘導し，血管壁肥厚やリモデリングを惹起 する．血管構造自体の変化が二次的に血管内皮 機能障害に関与することも考えられる．心血管 疾患と酸化ストレスの存在は悪循環を形成し， 動脈硬化の維持・進展につながると考えられる ${ }^{8}$. このような一連のプロセスは動物実験のデータ に基づくもので，はたしてヒトにおいて同じプ ロセスが存在しているかという証明はなかった. そこで我々は腎血管性高血圧に着目した。この 疾患では, Ang IIが過剩に産生され, NADPH オキシダーゼを活性化し, 活性酸素が産生され る。腎血管性高血圧はヒトにおける活性酸素過 剰産生モデルということができる．腎血管性高 血圧患者に血管形成術を施行して, Ang II を正常 レベルまで改善すると, 酸化ストレスの指標で ある血中MDAと尿中 8-OHdG排泄量がいずれも 正常レベルまで改善した. 血管内皮機能も術後
に正常レベルまでの改善を見た。 また, 術前に 抗酸化剂であるビタミンCを投与すると内皮機能 の改善がみられたが, 術後ではビタミンC投与の 影響は見られなかった。このことより，腎血管 性高血圧という特殊な例ではあるが，ヒトにお いてもRAS光進-NADPHオキシダーゼ活性化一活 性酸素過剩産生一血管内皮障害に至るプロセスが 存在していることが確認された ${ }^{9)}$.

その他, 内因性NO合成阻害物質の増加, Ang II, エンドセリン, トロンボキサン $\mathrm{A}_{2}$ といった内 皮由来血管収縮物質の増加なども血管内皮機能 異常に関与していると考えられている.

\section{4. 血管内皮機能の評価方法}

これまで血管内皮機能を評価（測定）するた めに様々な試みがなされている. 現段階でプレ チスモグラフを用いたものが最もよく血管内皮 機能を反映している。プレチスモグラフによる 方法はアセチルコリン，ブラジキニン，ヒスタ ミンといったNOのアゴニストあるいはL-NMMA などのNOアンタゴニストを四肢の動脈に選択的 に投与することにより血流量の変化で評価する 方法である。この方法は, 抵抗血管レベルでの 血管内皮機能を反映していると考えられる. NO のアゴニストやアンタゴニスト, 各種血管作動 物質を直接動注して評価する同法は, 特異性が 非常に高く, 少ない対象者でも有為差を確認で きる可能性があるが, カテーテルを前腕動脈や 冠動脈に挿入することや検査時間が長時間にわ たるため被検者への負担が大きくなるといった デメリットもある．超音波を用いての方法は四 肢の虚血反応性充血後のFMDを血管径の変化で 評価するものであり，導管血管レベルでの血管 内皮機能を反映していると考えられる．簡便か つ非侵襲的で, 検査時間も比較的短時間であり, 被検者への負担も少ないがやや特異性に欠ける. 冠動脈においても，血管作動物質を直接投与し て血管径や血流量を測定することにより内皮機 
能を評価することが可能である，腎動脈でも， 内皮機能の評価は可能であるが，直接血流量を 測定されたものはなくクリアランス法によって 測定したものを代用している.NOの代謝産物で あるNOx，あるいはcGMP，さらに血管内皮傷害 を反映する物質としてVCAM-1, ICAM-1, PAI$1, \mathrm{vWF}$ な゙のバイオマーカーの濃度を測定する ことにより血管内皮機能を評価しょうとするむ きもあるが, 直接にNO産生を反映していない可 能性があること, 測定上の問題などがあり, 現 在これらの測定はプレチスモグラフあるいは超 音波法（FMD）を用いての血管内皮機能評価法 の補助的な位置付けと考えられている. 血中あ るいは尿中のバイオマーカーを測定することが 最も簡便で非侵襲的であるが, 残念なことに評 価に耐えうるだけのバイオマーカーが存在して いないのが現状である。最近，血管内皮機能に おける血管内皮前駆細胞の役割が注目されてい る. 報告は少ないものの, 血中の血管内皮前駆 細胞数の測定が動脈硬化性疾患の有効なバイオ マーカーとなり得る可能性がある。バイオマー カーが血管内皮機能あるいは動脈硬化の指標と して特異性が高いものであれば，血中や尿中濃 度を測定することで評価可能となり被験者自体 に大きなメリットがあり，大規模臨床試験やコ ホート研究での利用も可能となってくる.

\section{5. 治療ターゲットとしての血管内皮機能}

臨床上，障害された血管内皮機能が可逆的な 否かは重要な問題である。血管内皮機能障害は 適切な薬物療法, 補充療法, 生活習慣修正など のインターベンションを加えることにより改善 可能である．血管内皮傷害から心血管合併症に 至るプロセスを断ち切ることは臨床上非常に重 要である. ACE阻害薬, Ang IIタイプ 1 受容体 阻害薬, スタチン, チアゾリン誘導体などの薬 剂は薬本来の作用以外の効果 (pleiotropic effects) により直接的に内皮機能を改善するという血管
保護作用をもつことが報告されている。また， 抗酸化物質 (ビタミンCやE)，NOの基質である L-arginine, さらにはNO合成酵素の補酵素であ るテトラハイドロビオプテリンの補充療法, あ るいは女性におけるエストロゲン補充療法など も，血管内皮機能を改善する。 また，適度な有 酸素運動, 減量, 禁煙や食塩摂取制限などの生 活習慣修正によっても内皮機能を回復すること が示されている。

興味深いことに，脳梗塞あるいは心筋梗塞な どの重篤な心血管合併症を有する非常に重症な 高血圧ではACE阻害薬による軽症から中等症の 高血圧にみられた血管内皮機能改善効果が認め られなかった ${ }^{10)}$.このことは血管内皮機能障害が 不可逆的になる前に治療することの必要性を示 していると思われる。重症末梢血管疾患の血管 内皮機能障害も通常の薬物治療では改善不可能 な最終的な段階にあると考えられる。このよう な症例では血管内皮機能改善以前の問題として, 肢自体の切断という状況に陷ることが多い。著 者らは最近, 従来の薬物治療, 補充療法, 生活 習慣の修正などのインターベンションにより改 善不可能であった重症末梢虚血性血管疾患患者 の血管内皮機能を骨髄細胞移植による血管新生 療法により，わずかではあるが改善できる可能 性を示した ${ }^{11)}$. 同様の血管内皮機能改善作用は血 管内皮増殖因子のプラスミド投与による血管新 生療法でも確認されている。直接のエビデンス は報告されていないが，血管内皮機能の改善が 心血管病発症の予防につながる可能性がある. 血管内皮機能は動脈硬化の第一段階としての重 要性に加え治療ターゲットとしても捉えること が可能である.

\section{おわりに}

血管内皮機能障害は動脈硬化発症の端緒であ る. 動脈硬化の第一段階として血管の最内層に 位置する血管内皮が障害される。さらに，発生 
した動脈硬化は多くの修飾を受けながら進展し， 最終段階として粥種の破綻に至る。これを我々 は心筋梗塞, 脳卒中として捉えることとなる. 血管内皮機能障害は動脈硬化の第一段階として のみならず, 動脈硬化の進展・維持・破綻にも 中心的役割をはたしている. 従って，血管内皮 機能障害を改善することは将来的に心, 脳血管 障害発症を抑制し, 生命予後を改善する可能性 があり, 臨床上意義深い. 多くのインターベン ションが血管内皮機能異常を改善することが知 られている。 これらのインターベンションの介 入により実際に心血管イベントが減少すること も報告されている．動脈硬化の治療ターゲット としてあるいは心血管イベント発症のサロゲー トエンドポイントとしての可能性も大いに期待 できる.

\section{文献}

1) Furchgott RF, Zawadzki JV: The obligatory role of endothelial cells in the relaxation of arterial smooth muscle by acetylcholine. Nature $288: 373-276,1980$.

2) Vanhoutte PM:Endothelium and control of vascular function. Hypertension 13:658-667, 1989.

3) Hsueh WA, et al:Endothelium in insulin resistance and diabetes. Diabetes Review 5 : 343-352, 1997.

4) Celermajer DS, et al : Cigarette smoking is associated with does-related and potentially reversible impairment of endothelium-dependent dilation in healthy young adults. Circulation 88 : 2149-2155, 1993.

5) Perticone F, et al: Prognostic significance of endothelial dysfunction in hypertensive patients. Circulation 104 : 191-196, 2001

6) Schachinger V, et al:Prognostic impact of coronary vasodilator dysfunction on adverse long-term outcome of coronary heart disease. Circulation 101 : 1899-1906, 2000.

7) Werner N, et al : Circulating endothelial progenitor cells and cardiovascular outcomes. N Engl J Med 353: 9991007, 2005.

8) Cai H, Harrison DG : Endothelial dysfunction in cardiovascular diseases : the role of oxidant stress. Circ Res 87: 840-844, 2001.

9) Higashi $Y$, et al:Endothelial function and oxidative stress in renovascular hypertension. N Engl J Med 346 : 19541962, 2002.

10) Higashi $Y$, et al: The severity of hypertension affects improved resistance artery endothelial function by angiotensin converting enzyme inhibition. J Cardiovasc Pharmacol 39: 668-676, 2002.

11) Higashi $Y$, et al: Autologous bone-marrow mononuclear cell implantation improves endothelium-dependent vasodilation in patients with limb ischemia. Circulation 109 : 1215-1218, 2004. 